\title{
EMBEDDED INNOVATION - STRATEGIC MANAGEMENT INCUBATORS FOR KNOWLEDGE HEGEMONY
}

\author{
I.A. Khota ${ }^{1}$ and L. Pretorius \\ RizQapital Management \\ University of Johannesburg, South Africa \\ irfaan.khota@gmail.com \\ Graduate School of Technology Management \\ University of Pretoria, South Africa \\ leon.pretorius@up.ac.za
}

\begin{abstract}
Global competitiveness and category leadership is the strategic challenge for South African innovators over the next decade. Within the context of engineering management, this research identifies the strategic drivers and corporate positioning necessary to meet this challenge and to create a vibrant manufacturing and innovation landscape leading to wealth for South African stakeholders. Focusing on the product life-cycle, the research identifies 'incubators of competitive advantage' within the areas of context-management, resource-management, and opportunitymanagement. The aim is to establish an organisational paradigm relating to the creation of intellectual capital and to knowledge management within these arenas, as sources of innovation and competitive advantage.
\end{abstract}

\section{OPSOMMING}

Wêreldwye kompetisie asook produkleierskap is strategiese uitdagings wat SuidAfrikaanse innoveerders in die volgende dekade gaan aanspoor. Hierdie navorsing identifiseer strategiese drywers en korporatiewe posisionering wat nodig is in die konteks van ingenieursbestuur om van hierdie uitdagings aan te spreek. Sodoende word ' $\mathrm{n}$ aktiewe vervaardigings- en innovasielandskap wat kan lei tot welvaartskepping vir Suid-Afrikaanse belanghebbendes bevorder. Deur te fokus op die produklewensiklus word 'omgewings van kompeterende voordeel' binne in konteks-, hulpbron- en geleentheidsbestuur geïdentifiseer. Die doel is om 'n organisasiekultuur te skep wat deurentyd intellektuele eiendom en kennisbestuur as bronne van innovasie en kompeterende voordeel vooropstel.

\footnotetext{
${ }^{1}$ Doctoral student in Engineering Management at the Faculty of Engineering and the Built Environment, University of Johannesburg
} 


\section{INTRODUCTION}

In a context where global economic growth is driven by the emergence of new markets, competitiveness depends on the management of multiple competencies in order to exploit resource and knowledge capital, together with the management ability to adapt better and faster than the competition to the dynamic and complex competitive landscape [18].

In the new business environment that is emerging where competencies in speed-tomarket and market intelligence are considered prerequisites for market leadership [1][9], the increasingly swift pace of change and the volatile competitor landscape threaten the success of ill-prepared organisations. This is particularly relevant in the dual-market scenario of physical and virtual markets [42][14].

In this environment, competitive differentiation and stakeholder value creation are driven by innovation [23], and competitive advantage is driven by a corporate competency and culture that espouses creative thinking [9]. This context, which is characterised by increasingly more complex products and services [14], requires design teams that are empowered with differentiated resources, where knowledge creation and retention promote sustainable organisational leadership [35].

Product development now requires a management obsession to ensure that all product development assets are efficiently utilised to target selected consumer markets [1]. This encompasses product design, manufacturing, intellectual property capitalisation, marketing capabilities, and strategic attitude, which serve as factors for differentiation by team rather than product [23][9].

Ultimately, product and service leadership will be achieved by those companies that are able to monitor and respond appropriately to the market input factors/demands that determine how customers can be acquired and retained efficiently [6][17][40][14][44]. The companies that succeed here are the ones that develop and implement a sector strategy, that have detailed knowledge of the strengths and weaknesses of the firm and inter-firm institutions within that sector. They typically understand the challenges and opportunities that the participants face, coupled with a collective vision that embraces these problems [3].

This paper proposes a management paradigm that focuses management attention across and within the product life cycle to promote the establishment of competitive advantages in product development, and that aligns business strategy inter alia with South African government policy, which supports infrastructure and systems that promote innovation [34].

\section{THEORETICAL HYPOTHESES}

This study is currently exploratory in nature [50], making use of secondary data mainly in the form of published literature to underpin the theoretical framework and hypotheses. This is supplemented by the authors' qualitative inductive reasoning to formulate the eventual framework. This is again in line with a methodology suggested by Cooper et al [50]. 
In seeking to identify management best-practice in this ever changing context of increasing competitiveness and complexity, our literature findings indicate that a multi-dimensional management approach is necessary, where management attention must focus across and within the product life cycle. The literature findings suggest that management should focus on three distinct strategy-influencing arenas (see Table 1), the so-called 'incubators of competitive advantage' (i.e. the management activities and organisational stances that promote and lead to the development of advantageous positions relative to competitors). These arenas encompass proven technology, performance, and process management activities as promoted by Six Sigma and Toyota and Chrysler's Keiretsu models (focusing on quality, trust, knowledge exchange, dedication of assets, segmentation of suppliers, branding, alliances) [15][29][16].

\begin{tabular}{|c|c|c|}
\hline CONTEXT & RESOURCES & OPPORTUNITY \\
\hline $\begin{array}{c}\text { The management focus } \\
\text { on context must seek to } \\
\text { ensure the } \\
\text { synchronisation of } \\
\text { organisational stance } \\
\text { with the evolution of } \\
\text { the market. }\end{array}$ & $\begin{array}{l}\text { The management focus } \\
\text { on resources must ensure } \\
\text { that direct and indirect } \\
\text { resources available to } \\
\text { the organisation are } \\
\text { channelled to support } \\
\text { product innovation and } \\
\text { leadership. }\end{array}$ & $\begin{array}{l}\text { The management focus on } \\
\text { opportunity must } \\
\text { establish an organisational } \\
\text { stance that is obsessed } \\
\text { with adding value and } \\
\text { leading the competitive } \\
\text { landscape, by being able } \\
\text { to anticipate future } \\
\text { product and service } \\
\text { drivers and then } \\
\text { capitalising on this } \\
\text { knowledge. }\end{array}$ \\
\hline
\end{tabular}

Table 1: Strategy incubation arenas

The focus on the abovementioned arenas specifically is motivated by a product management strategy to prolong the phases of product maturity, minimise or eliminate product decline, and stimulate growth through organisation-wide innovation.

\subsection{The contextual challenge}

The modern era in business is characterised by constant change owing to greater creativity and application of knowledge [11][9][22]. This is typified by a shift in the world economy where technology is the key driver of increased efficiency [14], effecting a reduction in both operating and market costs [40]. Coupled to this is a shift in market orientation where the pace of change requires a focus on tomorrow's consumers, rendering today's markets irrelevant [5].

This market shift is characterized by the following phenomena:

- a global shift from an industrial to knowledge- and information-based economies, driven by revolutionary developments in communication and information technology [22]; 
- $\quad$ increased market volatility and opportunity [42][14][22];

- dramatic changes in relationships and trading patterns between business partners, competitors, customers, and regulators of markets [46][14][22];

- $\quad$ an exponential increase in the pace of new innovations that alter the way society works and functions, termed 'killer applications' [14] - from an occurrence of about one every five or ten years during the Industrial Revolution, the rate has increased to about one or two 'killer applications' a year [39].

- markets now facilitate large-scale interaction of market participants [41] through the automation of transactions, with reduced transaction costs for all, expanding consumer choice, and the access of suppliers to new customers [24][45].

These phenomena make it increasingly difficult for the new product development (NPD) organization, which must maintain a clear vision of its core business with a clear selection of the target markets which the company aims to serve [1]. At the same time generating profitable products at high speed in response to 'want it now' customers and fast-moving competition is of paramount importance [49].

This context of change and challenge, market turbulence, technological turbulence, and intense competition increasingly demands an organisational stance of militarylike readiness in order to position those best prepared to take advantage of opportunities as they present themselves [26][42]. Delivering the right products on time and defect free to customers who expect the rapid availability of products [49] necessitates the continuous review of the organisation's market orientation relative to the prevailing context [31][28].

\begin{tabular}{l|l|l|}
\cline { 2 - 3 } \multicolumn{1}{l|}{ Long } & $\begin{array}{l}\text { Yesterday's companies: } \\
\text { Old economy; little competition; } \\
\text { calculated risk; low rate of change; } \\
\text { not applicable in today's business } \\
\text { context of competition and change. }\end{array}$ & $\begin{array}{l}\text { Today's analysers: } \\
\text { Old context companies such as } \\
\text { pharmaceuticals. Threatened by } \\
\text { increasing rate of change of } \\
\text { technology, with increased } \\
\text { competition. }\end{array}$ \\
\cline { 2 - 3 } $\begin{array}{l}\text { Product } \\
\text { development } \\
\text { cycle }\end{array}$ & $\begin{array}{l}\text { Today's defenders: } \\
\text { Current market leaders (old context) } \\
\text { having relatively little competition; } \\
\text { increasing rate of change. }\end{array}$ & $\begin{array}{l}\text { New context companies: culture of } \\
\text { change, sense of market } \\
\text { opportunities and trends, sense of } \\
\text { competition, supply chain } \\
\text { manipulators. }\end{array}$ \\
\cline { 2 - 3 } Short & \multicolumn{2}{|c|}{ Risk }
\end{tabular}

Figure 1: Company stance, risk, and product cycle (Adapted from [10][31]) 
The market leaders will be those who will be able to create tommorrow's competitive advantages faster than competitors mimic the prevailing ones [20]. Rather than structure, success in the future will be for those companies that can pioneer demand by being able to supply when demand takes off without forecasts and against odds. This requires different capabilities in the way that this future demand has to be anticipated [32]. The market orientation is influenced by supplyside and demand-side factors that determine the association between market orientation and business performance. This is characterised by high risk, owing to increased experimentation and shorter product development cycles as a result of increased demand and competition, as illustrated in Figure 1 above.

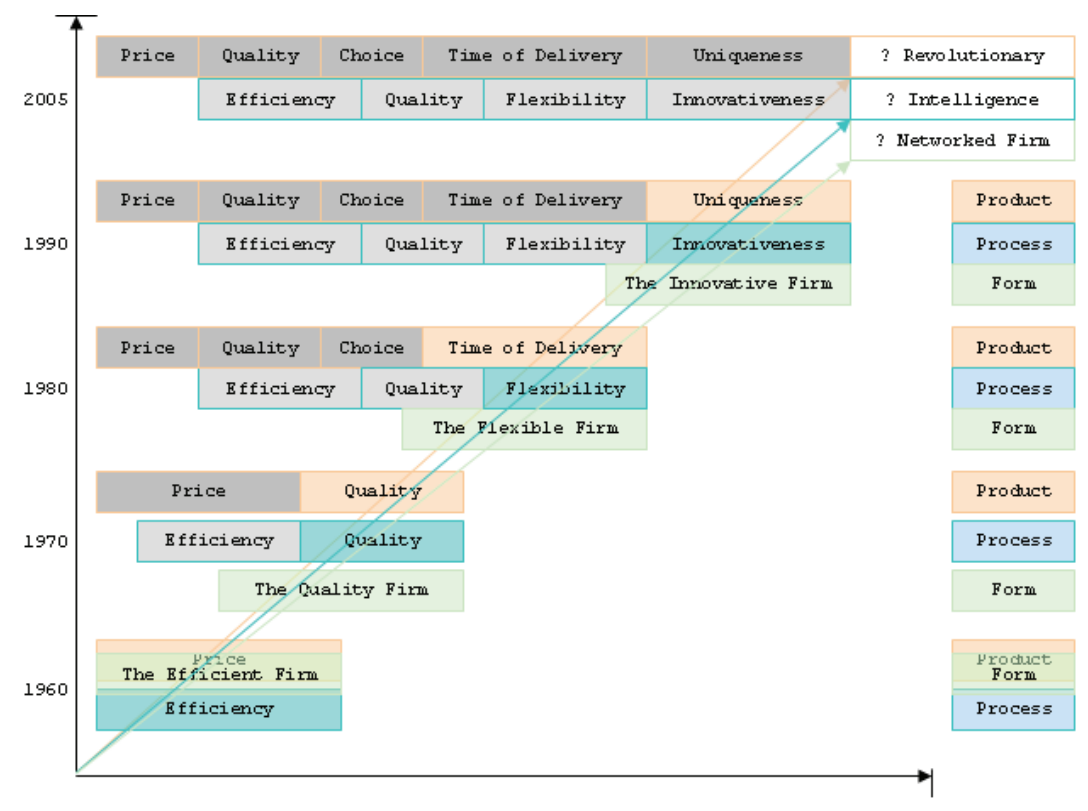

Figure 2: Product, process and form evolution (Adapted from [23][4])

The discontinuity in experience introduced by transitions requires industry leaders to address new realities in ways that are radically and qualitatively different from anything they have known before. They are asked to 'jump the curve' [22], and in so doing to succeed in faster and cheaper development and deployment of product and service offerings that are now a requirement for market success [32][14].

The evolution of dominant designs correlates strongly with the application of new technology. Such 'disruptive technology' enables new companies to dominate the new or altered industry; mastering this evolution requires evolving the innovation with the innovation arena [23]. 
The changes due to shifts in marketplace and consumer preference, as depicted in Figure 2 above, suggest that experts' systems are less reliable than the management of knowledge over time [23]. It is no longer effective or efficient to develop products for domestic markets with the hope of introducing these to external markets later: new context development requires strategic proficiency, focus, goal orientation, measurement, accurate competitive situation analysis, competitor profiling, and an understanding of corporate resources and capabilities [1]. Management needs to use this disposition, achieved by establishing an inherent corporate ability to innovate in order to increase its 'value added', to make better products more efficiently [38].

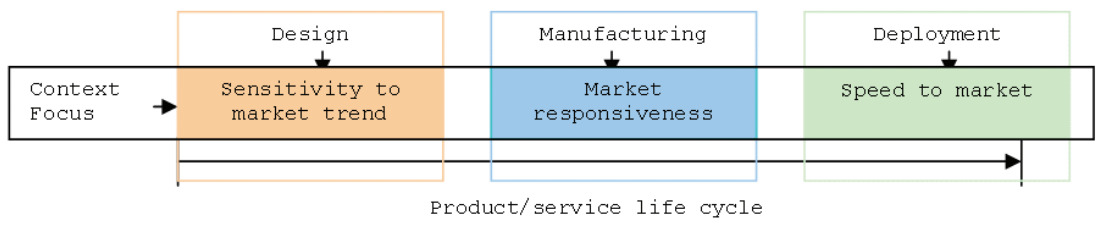

Figure 3: Contextual strategic levers

Managing the context arena across the product life cycle (see Figure 3) mandates functional competencies, where:

- $\quad$ design teams are sensitive to market trend to the extent of being able to predict preference shifts;

- $\quad$ manufacturing is inexpensively responsive to market changes; and

- $\quad$ speed-to-market and extensiveness of reach establish contextual advantages.

We describe an organization with such a disposition as being 'contextually embedded'.

\subsection{The resources challenge}

Complementary to being 'contextually embedded', the organization also needs to be positioned so that its resources converge toward product leadership.

Adopting the 'high road' to competitiveness focuses on improving productivity and profits rather than containing cost [38]. In addition to this, successful product development is driven by a deep understanding and nurturing of the predominant corporate culture, characterised by:

- a culture of innovation (promoted by a balanced orientation in manufacturing, distribution, technology, vendors, and the market)[1];

- $\quad$ a culture of creative problem-solving (a focus on continual competency upgrading, shared knowledge, shared experiences, ownership of work, 
teamwork, adaptation to evolving contextual demands and company objectives, a concentration on being entrepreneurial, a diffusion of highperformance work ethic, the fostering of open networks with a focus on establishing trust, and cooperation/collaboration with alliances that promote innovation and learning) [3][38][9];

- $\quad$ effective knowledge management (to ensure that core competencies embodying knowledge and capabilities are protected with key stakeholders) [36][33].

The NPD organization needs to outline the strategic role of product development and the allocation of its resources to achieve product-intensive strategies, so that product decision criteria that guide NPD initiatives are established [1]. Resourceallocation should avoid too many fixed assets to promote flexibility [14]. Furthermore, vertical integration may be preferred when customer demand exceeds the company's prevailing technology offering [6].

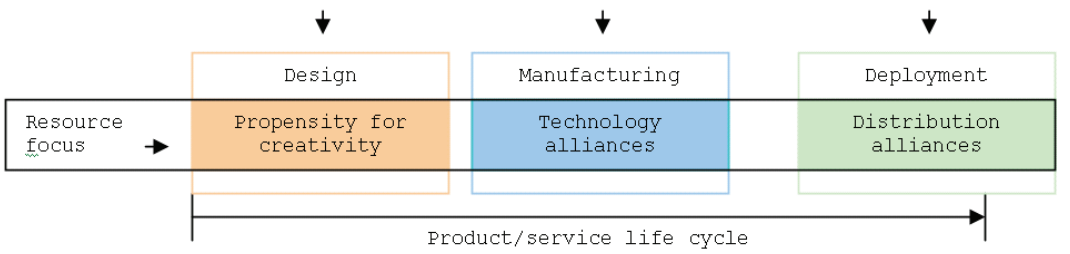

Figure 4: Resource strategic levers

Ultimately the desired outcome of tangible resources should be to enhance innovation and service delivery. From an operational and manufacturing perspective, resources should be positioned to:

- $\quad$ adopt simultaneous business processes that promote quality and speed-tomarket to achieve enhancements in productivity (e.g 'Just-in-Time', 'Activity-Based-Costing' and 'Total Quality Management') [3].

- $\quad$ optimise flexibility that empowers centralized or distributed decisionmaking capabilities, depending on the prevailing context [23];

- develop and integrate the respective alliance networks to ensure effective linkages between the evolving local technologies or systems and the global or regional production network [43].

Managing the resource arena across the product life cycle (see Figure 4) mandates functional competencies, where:

- $\quad$ resources converge to establish an organisation that is a 'creative entity', one which is able to translate its 'contextual embeddedness' into valueadded products; 
- $\quad$ manufacturing and technological gaps are mitigated by carefully chosen alliances; and

- $\quad$ the supply-chain is efficient and cost-effective through marketing and distribution partnerships.

We describe an organisation with such a disposition as being 'creatively charged and strategically networked'.

\subsection{The opportunity challenge}

Whilst a management focus on creating a contextually embedded, creatively charged, and strategically networked organisation may result in contemporary product success and leadership, the organization also needs to have a disposition that embraces the 'waves of change' that alter context and resources. The reason for this is that future markets and trends may be internally anticipated, and competitive advantages sustained.

As witnessed in the last century, numerous market players have assumed dominant positions and leap-frogged competitors through successful innovation [21]. As the pace of technological developments continues to accelerate across various sectors, shifts in standards and needs are also becoming more common and more pronounced, resulting in more windows of opportunity for innovative challengers [30].

Building barriers to entry has limited the number and intensity of competition [25] with respect to innovative challengers. However, these defensive barriers seem to provide little or no protection for incumbents [30] since innovators tend to alter industry structure [19] and thereby exploit new opportunities.

Accurate role perception (the roles that need to be enacted to confront challenges and proactive action) and anticipation of future trends are imperative for market leaders [22]. Alternative explanations of the future prevent complacency that the current explanation is the only one and is absolutely right [13]. Leadership requires a company to have a clear vision of its desired future, with a perpetual curiosity for learning and no fear of failure [2].

An organisational ability to define the landscape of any problem or opportunity and the ability to look at things in different ways creates a better understanding of the possibilities [12][13]. Coupled with continual organisational upgrading, driven by inspiration, transformation, flexibility, knowledge, creativity, and consciousness of change, this results in sustainable leadership [37][48]. From a strategic perspective, management needs to coordinate innovation-cycle management with barrier building, driven by a pervasive market-orientated organisational culture [21].

The opportunity arena is managed through a deep understanding and knowledge of the drivers of change, emerging technologies, new knowledge creation, and its applicability to product development. Organisations need to seek to identify what specific opportunities in the future directly relate to the organisation's current skills and capabilities [5]. It is the companies that are able to cut through complexity, 
asking the right questions and solving the right problems, that are adept at smart thinking and that generate smart solutions [33].

This requires an organisational passion for knowledge and learning, continually asking questions that demand innovative solutions. As indicated in Figure 5 , the opportunity and context arenas have strong knowledge and informational linkages that encourage innovation. As Clarke [8] identifies, the best solutions are often achieved by oscillating between a logical and creative or unstructured approach, where proven ways of doing things are complemented by a flexible broad-thinking perspective.

The fundamental difference is that contextual embeddedness ensures success in product development for today's consumers, whilst opportunity management encourages preparation and delivery for tomorrow's consumers.

\section{Context:}

Trend \& responsiveness

- Who are our customers?

- What are their motives and goals?

- What do they value in the types of products we deliver?

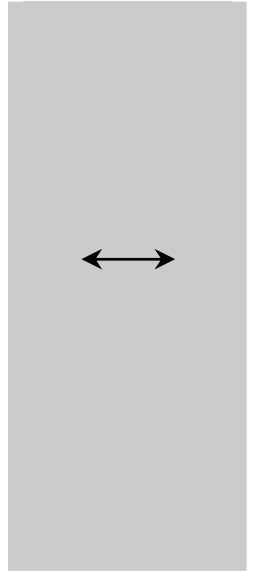

Opportunity:

Knowledge and innovation

- What can we substitute?

- What can we combine?

- What can we adapt?

- What can we magnify, miniaturise, multiply?

- What can we put to other uses?

- Can we rearrange or reverse?

- What else? Who else? Where else?

Figure 5: Linkages between context and opportunity arenas (Adapted from [23][8])

The common factor across the opportunity arena is the acquisition, assimilation, and management of knowledge, and the generation of new knowledge, all of which establishes the organisational 'intelligence' leading to leadership. Knowledge is the key differentiator in the new context. In order to exploit this knowledge, knowledge strategy formulation, choice, and attention to resource allocation must be incorporated into the strategic framework [47].

In confronting market competitors, the primary objective is to overcome the adversaries so that profitable sales - with profitable product to clearly targeted customers - are achieved. The leaders are able to match their strategic and operational prowess with the appropriate tactical agility necessary to capture and retain the consumer [1][23]. 


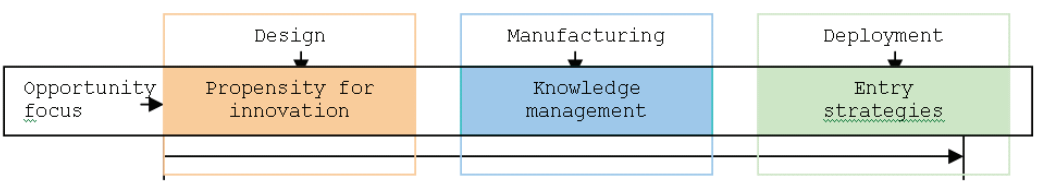

Product/service life cycle

Figure 6: Opportunity-creating strategic levers

Managing the opportunity arena across the product life cycle (see figure 6) mandates functional competencies that:

- $\quad$ create and nurture innovation in all its activities;

- $\quad$ actively manage its intellectual property for economic benefit; and

- $\quad$ tread market-engaging strategies that create new markets and marketaccess opportunities.

We describe an organisation with such a disposition as being 'knowledge proactive'.

\section{CONCLUSION}

A firm's competitiveness depends on its ability to connect and manage its numerous assets and promote participation in the global network of infrastructure [18][29]. The management challenge for export growth for South Africa as part of the global network is thus to expand manufacturing in the current comparative advantage sectors, coupled with an expansion of service-driven sectors. This may be achieved through investment in transport and technological and communications infrastructure, focusing on technological innovation and application, particularly targeting growth in South-South trade [7][27].

In meeting this challenge, strategic product development requires active management attention across the three arenas of context, resources, and opportunity. Organisational leadership in these arenas is promoted by developing the four distinct strategic dispositions that will incubate differentiated products and competitive advantages, namely:

1) contextual embeddedness (i.e. a management sensitivity and reactivity to the dynamics that evolve and revolutionise the prevailing and unfolding context);

2) creative charge (i.e. an obsession with creativity and innovation);

3) strategic networks (i.e. engaging and managing enduring alliances and collaboration across all product development initiatives); and

4) knowledge proactivity (i.e. actively managing knowledge and intellectual property for advantage and economic benefit).

Establishing such dispositions should ultimately position the organisation to extend the 'growth phase' of the product life cycle and increase the scope of application of 
product innovations. This should ultimately lead to enhanced product profitability and product category leadership.

Current and future research on the proposed context, resource, and opportunity framework includes more formalised hypothesis testing. This forms part of the ongoing doctoral research of the first author, and will be reported on in future.

\section{REFERENCES}

[1] Bean, R. \& Radford, R. 2000. Powerful products - Strategic management of successful new product development, AMACOM, New York.

[2] Bennis, W. 1989. On becoming a leader, Addison-Wesley Publishing Company, Massachusetts.

[3] Best, M. 2004. The productivity triad approach and the role of institutions in competitiveness. The Dti/UNIDO Competitiveness Conference Program An institutional approach to competitiveness; Pretoria, South Africa; June.

[4] Bolwijn, P.T. \& Kumpe, T. 1990. Manufacturing in the 1990s: Productivity, flexibility and innovation, Long Range Planning, 23 (4), 44-57.

[5] Buggie, F.D. 2001. The four phases of innovation, in The Journal of Business Strategy, September/October, 36-42.

[6] Christensen, C.M. 2001. The past and future of competitive advantage, in MIT Sloan Management Review, Winter, 105-109.

[7] Global Competitiveness Report 2006-2007. World Economic Forum; http://www.weforum.org. Accessed 8 November 2006

[8] Clark, C.H. 1980. Idea management: How to motivate creativity and innovation, AMACOM, New York.

[9] Coade, N. 1997. Smart strategies - be creative: The toolkit for business success, International Thomson Business Press, London.

[10] Crol, J.B. 2000. Creating support for a change in strategy, in International Journal of Technology Management, 19 (6), 15-28.

[11] David, F.R. 1998. Strategic management concept, Prentice-Hall, New Jersey.

[12] De Bono, E. 1967. The 5-day course in thinking, Penguin Books, England.

[13] De Bono, E. 1990. Six thinking hats, Penguin Books, England.

[14] Downes, L. \& Mui, C. 1998. Unleashing the killer app - Digital strategies for market dominance, Harvard Business School Press, Boston, Massachusetts. 
[15] Dyer, J.H. 2000. Collaborative advantage: Winning through extended enterprise supplier networks, Oxford University Press, Oxford.

[16] Eckes, G. 2000. The Six Sigma revolution: How General Electric and others turned process into profits. John Wiley \& Sons.

[17] Feeny, D. 2001. Making business sense of the E-Opportunity, in MIT Sloan Management Review, Winter, 41-51.

[18] Garelli, S. 2006. The World Competitiveness Landscape in 2006; IMD World Competitiveness Yearbook 2006, IMD World Competitiveness Centre. http://www.imd.ch/research/centers/wcc/index.cfm

[19] Gort, M. \& Wall, R.A. 1984. The Effect of Technical Change on Market Structure, in Economic Inquiry, Vol 22, October, 668-675.

[20] Hamel, G. \& Prahalad, C.K. 1989. Strategic intent, in Harvard Business Review, May/June.

[21] Han, J.K., Kim, N. \& Kim, H. 2001. Entry barriers: A dull-, one-, or twoedged sword for incumbents? Unravelling the paradox from a contingency perspective, in Journal of Marketing, Vol.65, January, 1-14.

[22] Imparato, N. \& Harari, O. 1996. Jumping the curve: Innovation and strategic choice in an age of transition, Jossey-Bass Publishers, San Francisco.

[23] Janszen, F. 2000. The age of innovation - Making business creativity a competence not a coincidence, Pearson Education Limited, London.

[24] Kaplan, S. \& Sawhney, M. 2000. E-Hubs: The new B2B marketplaces, in Harvard Business Review, May-June, 97-103.

[25] Karakaya, F. \& Stahl, M.J. 1989. Barriers to entry and market entry decisions in consumer and industrial goods market, in Journal of Marketing, Vol 53, April, 80-91.

[26] Kenny, D. \& Marshall, J.F. 2000. Contextual marketing - The real business of the Internet, in Harvard Business Review, November-December, 119-125.

[27] Krakoff, C. 2003. Key potential export markets and the market access barriers facing Southern African exporters. The Services Group; South African Global Competitiveness Hub. http://www.satradehub.org. Accessed 08 November 2006.

[28] Kohli, A.K. \& Jaworski, B.J. 1990. Market orientation: The construct, research propositions, and management implications, in Journal of Marketing, 54 (April), 1-18. 
[29] Liker, J.K. 2003. The Toyota way: 14 management principles from the world's greatest manufacturer, Mc-Graw Hill.

[30] Markides, C. 1997. Strategic innovation, in Sloan Management Review, Vol 38, Spring, 9-23.

[31] Matsuno,K. \& Mentzer, J. 2000. The effects of strategy type on the market orientation-performance relationship, in Journal of Marketing, 64 (October), $1-64$.

[32] Metzemaekers, D.A.M.M. 2000. Critical success factors in technology management, in International Journal of Technology Management, 19 (6), 583-585.

[33] Mitroff, I. 1997. Smart thinking for crazy times - The art of solving the right problems, Berrett-Koehler Publishers, San Francisco.

[34] Ngubane, B.S. 2003. Session on "Recovering spaces for development policy: Special and differential treatment, innovation and sustainable development"; Minister of Arts, Culture, Science and Technology of Republic of South Africa; Cancun Trade and Development Symposium; September.

[35] Nonaka, I. 1991. The knowledge creating company; in Harvard Business Review, November-December.

[36] Norman, P.M. 2001. Knowledge protection mechanisms, in Business Horizons, November-December, 51-60.

[37] Parikh, J. 1994. Managing yourself - Management by detached involvement, Blackwell Publishers, Oxford.

[38] Pietrobelli, C. \& Rabelloti, R. 2004. Competitiveness and upgrading in clusters and value chains - The case of Latin America; The Dti/UNIDO Competitiveness Conference Program - An institutional approach to competitiveness; Pretoria, South Africa; June.

[39] Pitt, L. 1999. Strategy in the digital age - Five new forces?, in E-conomy: Management und okonomie in digitalen kontexten - Wittener Jahrbuch fur Okonomische Literatur, November, 117-124.

[40] Porter, M.E. 2001. Strategy and the Internet, in Harvard Business Review, March, 63-78.

[41] Postma, P. (1999): The new marketing era - Marketing to the imagination in a technology-driven world. New York: McGraw-Hill Ltd.

[42] Prahalad, C.K. \& Krishnan, M.S. 1999. The new meaning of quality in the information age, in Harvard Business Review, September-October, 109-118. 
[43] Radosevic, S. 2004. Electronics industry in Central Europe: Explaining the emergence of a new global production location; The DTI/UNIDO Competitiveness Conference Program - An institutional approach to competitiveness; Pretoria, South Africa; June.

[44] Rayport, J.F. \& Sviokla, J.J. 1994. Managing in the marketspace, in Harvard Business Review, November-December, 141-150.

[45] Rayport, J.F. \& Sviokla, J.J. 1995. Exploiting the value chain, in Harvard Business Review, November-December, 75-85.

[46] Venkatraman, N. 2000. Five steps to a dot-com strategy: How to find your footing on the Web, in Sloan Management Review, Spring, 15-28.

[47] Von Krogh, G., Nonaka, I. \& Aben, M. 2001. Making the most of your company's knowledge: A strategic framework, in Long Range Planning, Vol 34, 421-439.

[48] Wainwright, G. 1993. Essential skills for life and work, Pfeiffer \& Company, San Diego.

[49] Wetzer, M. 2003. Today's product life cycle management: Achieving product development breakthroughs, in Accenture - Outlook, March, http://www.accenture.com).

[50] Cooper, D.R. \& Schindler, P.S. 2003. Business research methods, eighth edition, McGraw Hill, New York. 